\title{
Analysis of the Cell Wall Constituents of Corynebacterium genitalium
}

\author{
A. T. EVANGELISTA, $\dagger$ A. SAHA, ${ }^{\prime}$ M. P. LECHEVALIER, ${ }^{2}$ aNd G. FURNESS
}

Department of Microbiology, College of Medicine and Dentistry of New Jersey, Graduate School of Biomedical Sciences and N.J. Medical School, Newark, New Jersey 07103, ${ }^{1}$ and Waksman Institute of Microbiology, Rutgers University, The State University of New Jersey, New Brunswick, New Jersey $08903^{2}$

Cell walls of Corynebacterium genitalium (three strains) were analyzed for their content of neutral sugars, amino acids, amino sugars, and corynomycolates. Analyses of the walls of a strain of $C$. xerosis, a bona fide member of the genus, were effected for purposes of control. Walls of each of the four strains contained arabinose, galactose and alanine, glutamic acid, and diaminopimelic acid in similar molar ratios, as well as corynomycolic acids ranging from 32 to 36 in numbers of carbon atoms. This confirmed that they are Corynebacterium species. However, distinct differences in cell wall composition were found between C. xerosis and the strains of $C$. genitalium.

Among corynebacteria found in the male and female urogenital tracts (8), some have been associated with so-called nonspecific urethritis (NSU) $(3,7)$ and some have been associated with epididymitis $(6,9)$. Certain strains appear to be capable of initiating NSU (4), whereas others exist commensally with their hosts (5). These corynebacteria have been designated $\mathrm{Cor}$ ynebacterium genitalium, a species which encompasses five (I through V) biological varieties regarded as pathogenic and six (C-1 through $\mathrm{C}$ 6) biovars deemed nonpathogenic (G. Furness and A. T. Evangelista, Invest. Urol., in press). The bacteria assigned to the genus Corynebacterium are facultatively aerobic, gram-positive to gram-variable, nonmotile, rodlike, tapered bacteria, producing metachromatic granules and growing as black colonies on tellurite agar (1). C. genitalium not only has these characteristics, but also produces catalase and forms small circular colonies 1 to $2 \mathrm{~mm}$ in diameter on Tween 80 agar and NSU chocolate agar (Furness and Evangelista, in press). Moreover, biovars I through $\mathrm{V}$ are fructose negative and biovars $\mathrm{C}$ 1 through C-6 are fructose positive. They are differentiated by differences in their ability to ferment dextrose, fructose, and starch, to produce gelatinase, lipase, and urease, and in their requirement for $\mathrm{O}_{2}$ only when grown on Tween 80 agar (Furness and Evangelista, in press). Members of the genus Corynebacterium, sensu strictu, possess a cell wall structure characterized by a peptidoglycan containing alanine, glutamic acid, and meso-diaminopimelic acid and an arabinogalactan polysaccharide (20) occur-

$\uparrow$ Present address: Department of Microbiology and Immunology, Temple University School of Medicine, Philadelphia, PA 19140. ring in conjunction with corynomycolic acids $(12,22,24)$. Here we present data which show that representative strains of $C$. genitalium possess cell walls characteristic of the genus Corynebacterium (19).

\section{MATERIALS AND METHODS}

C. genitalium 392-1 (biovar I) and 321D (biovar IV) are pathogens which were cultured from patients with acute "coryneform urethritis" (Furness and Evangelista, in press), whereas strain 148A (biovar C-1) was isolated from the normal urogenital tract of a male control (4, 5; Furness and Evangelista, in press). Corynebacterium xerosis ATCC 373 was obtained from the American Type Culture Collection.

The bacteria for analysis were obtained by inoculating Tween 80 agar plates with a Tween 80 broth culture (8) and incubating the plates for 48 to $72 \mathrm{~h}$ when the growth was confluent. All cultures were incubated at $37^{\circ} \mathrm{C}$. Thereafter, the organisms were washed off the agar with sterile distilled water and sedimented by centrifugation at $10,000 \times g$ for $15 \mathrm{~min}$, and the supernatant was discarded. When $15 \mathrm{~g}$ (wet weight) of each strain was obtained, $5 \mathrm{~g}$ was analyzed for the cell wall components and $10 \mathrm{~g}$ was analyzed for detecting the presence of the mycolates.

Preparation of cell walls. Cell wall preparations were obtained by a modification of the method of Kanetsuna (10). The 45\% (wt/vol) buffered phenol and $90 \%$ (wt/vol) buffered phenol were prepared by adding appropriate quantities of $0.05 \mathrm{M}$ tris(hydroxymethyl) aminomethane-hydrochloride buffer (pH 7.2) to phenol, analytical-grade reagent (Fisher, Springfield, N.J.), and adjusting to $\mathrm{pH} 7.2$ with $2 \mathrm{~N}$ $\mathrm{NaOH}$. A 5-g (wet weight) amount of cells was suspended in $20 \mathrm{ml}$ of $45 \%$ buffered phenol in a $30-\mathrm{ml}$ Corex tube (Corning Glass, Corning, N.Y.) and disrupted by sonically extracting the suspension at $25^{\circ} \mathrm{C}$ by means of a Branson Sonifier (Heat Systems Co., New York). When the phenol started to boil after about 2 min of sonic extraction, the suspension was 
cooled in ice water. The process was repeated, and the resulting emulsion was separated into the two layers of phenol and buffer by centrifugation at $27,000 \times g$ for $30 \mathrm{~min}$ at $4^{\circ} \mathrm{C}$ in a Sorvall RC-5 refrigerated centrifuge (Dupont, Norwalk, Conn.). The pellet and the material at the phenol-buffer interface were pooled, and the supernatant was discarded. The $45 \%$ buffered phenol extraction, sonic extraction, and centrifugation procedures were repeated four additional times. Thereafter, it was confirmed that only a few of the cells in a Gram-stained smear of the residue were still intact. Phenol remaining in the cell wall fraction was removed by washing twice with acetone, once with ether, and twice with distilled water. At every stage, the cell wall fraction was sedimented by centrifugation at $27,000 \times g$ for $20 \mathrm{~min}$ at $4^{\circ} \mathrm{C}$. The fraction was digested for $2 \mathrm{~h}$ with $0.1 \%$ (wt/vol) trypsin (Worthington Biochemicals Corp., Freehold, N.J.) in 0.05 M tris(hydroxymethyl)aminomethane-hydrochloride buffer $\left(\mathrm{pH} \mathrm{7.2)}\right.$ at $37^{\circ} \mathrm{C}$ with continuous agitation on a rotary shaker (New Brunswick Scientific Co., New Brunswick, N.J.). The undigested residue was removed by centrifugation at $27,000 \times g$ for $20 \mathrm{~min}$ at $4^{\circ} \mathrm{C}$, the trypsin was decanted, and sonic extraction of the residue was repeated first in $45 \%$ buffered phenol and then in $90 \%$ buffered phenol. Only the material at the interface of the $90 \%$ phenol-buffer was collected, the supernatant fluid and the pellet being discarded. The phenol in this fraction was removed by washing with acetone followed by ether and distilled water. The residue was dried in vacuo over $\mathrm{CaSO}_{4}$ at $25^{\circ} \mathrm{C}$. About $60 \mathrm{mg}$ of cell wall material containing the mycolic acid-arabinogalactan-peptidoglycan (MA-AGPG) complex (11) was obtained from $5 \mathrm{~g}$ (wet weight) of bacteria.

Neutral sugar analysis. A $10-\mathrm{mg}$ amount of the dried cell wall residue, which contained 24 to $30 \%$ neutral sugars as estimated by the anthrone (13) and orcinol (2) methods using galactose and arabinose, respectively, as standards, was hydrolyzed in vacuo in $1 \mathrm{ml}$ of $2 \mathrm{~N} \mathrm{HCl}$ in a sealed ampoule (Wheaton, Millville, N.J.) at $100^{\circ} \mathrm{C}$ for $6 \mathrm{~h}$. The hydrolysate was dried in vacuo over $\mathrm{NaOH}$ pellets, suspended in $3 \mathrm{ml}$ of $0.1 \mathrm{M}$ sodium borate buffer ( $\mathrm{pH} 8.00)$ (11), and filtered through a $0.45-\mu \mathrm{m}$ membrane filter (Millipore Corp., Bedford, Mass.). Analysis of the neutral sugars was performed by a modification of the methods of Kesler (11) and Lee et al. (16) by use of a Technicon Autoanalyzer (Technicon Corp., N.Y.) equipped with a column $(0.6$ by $68 \mathrm{~cm})$ packed with Chromobeads $S$ resin (Technicon). The column was standardized by analyzing a calibration mixture of $0.1 \mu \mathrm{mol}$ each of $\mathrm{D}$ mannose, L-arabinose, D-galactose, D-glucose, L-rhamnose, and D-ribose (Calbiochem, Los Angeles, Calif.).

Amino acid and amino sugar analyses. A 1-mg amount of the dried MA-AG-PG material, which contained 12 to $18 \%$ protein as estimated by the method of Lowry et al. (17), was hydrolyzed at $100^{\circ} \mathrm{C}$ in sealed tubes either in $6 \mathrm{~N} \mathrm{HCl}$ for $18 \mathrm{~h}$ for the amino acid determination or in $4 \mathrm{~N} \mathrm{HCl}$ for $8 \mathrm{~h}$ for the amino sugar analysis. The hydrolysis tubes were intermittently evacuated by a vacuum pump and flushed with nitrogen and sealed in vacuo. After hydrolysis, $\mathrm{HCl}$ was removed by a rotary evaporator under reduced pressure, and the dried residue was dissolved in 0.35 $\mathrm{M}$ sodium citrate buffer ( $\mathrm{pH} 2.2$ ). Analyses of the amino acids and amino sugars were performed by a modification of the method of Spackman et al. (23) on a Beckman $120 \mathrm{C}$ amino acid analyzer which was connected to a general-purpose, on-line laboratory computer (Infotronics CRS 1000, Columbia Scientific Instruments, Austin, Tex.). The buffer flow rate was 70 $\mathrm{ml} / \mathrm{h}$, and the ninhydrin flow rate was $35 \mathrm{ml} / \mathrm{h}$.

The quantitation of the acidic and neutral amino acids and diaminopimelic acid (Dpm) and muramic acid (Mur) was performed on a UR 30 column ( 0.9 by $58 \mathrm{~cm}$; Beckman). The analysis was carried out on this column at $53.5^{\circ} \mathrm{C}$ for a total of $140 \mathrm{~min}$ with $0.2 \mathrm{M}$ sodium citrate buffer ( $\mathrm{pH} 3.56$ ) for $43 \mathrm{~min}$ followed by citrate buffer at $\mathrm{pH} 4.26$. The $\mathrm{Dpm}$ determination was conducted at $53.5^{\circ} \mathrm{C}$ for $200 \mathrm{~min}$ with $0.2 \mathrm{M}$ sodium citrate buffers ( $\mathrm{pH} 3.44$ and $\mathrm{pH} 4.26$ ) with a buffer change at $107 \mathrm{~min}$. The Dpm was eluted at $137 \mathrm{~min}$. The Mur was analyzed on the same column with 0.2 $\mathrm{M}$ citrate buffer ( $\mathrm{pH} 3.21)$ at $32.5^{\circ} \mathrm{C}$ for $110 \mathrm{~min}$, with Mur emerging at $63 \mathrm{~min}$.

The basic amino acids were quantitated by using a PA 35 column ( 0.9 by $7 \mathrm{~cm}$; Beckman) and developed with $0.2 \mathrm{M}$ sodium citrate buffer $\left(\mathrm{pH} 5.26\right.$ ) at $53.5^{\circ} \mathrm{C}$ for $65 \mathrm{~min}$. The quantitation of glucosamine $\left(\mathrm{GlcNH}_{2}\right)$ and galactosamine $\left(\mathrm{GalNH}_{2}\right)$ was performed on a PA 35 column ( 0.9 by $15 \mathrm{~cm}$; Beckman) with $0.2 \mathrm{M}$ sodium citrate buffer (pH 5.21 ) at $53.5^{\circ} \mathrm{C}$ for $140 \mathrm{~min}$.

A standard amino acid mixture (Beckman) containing $10 \mathrm{nmol}$ of each amino acid in a $200-\mu \mathrm{l}$ sample volume was used for calibration, as were 10 -nmol standards of Dpm, Mur, Glc $\mathrm{NH}_{2}$, and $\mathrm{GalNH}_{2}$ (Sigma).

Analysis of mycolates. A 10-g (wet weight) amount of each strain of corynebacteria was used for the extraction. Qualitative and quantitative analyses of mycolates in the extracts were performed by the methods of Lechevalier et al. $(14,15)$. The cells were boiled for $7 \mathrm{~min}$ in $50 \mathrm{ml}$ of $2 \%$ methanolic $\mathrm{KOH}$ in a water bath at $100^{\circ} \mathrm{C}$. The hot cell suspension was filtered through fluted Whatman no. 1 filter paper and rinsed twice with hot methanol, and the solvent was discarded. The cells were then extracted twice in succession for $2 \mathrm{~min}$ with boiling methylene chloride. The cells were removed by filtration using Whatman no. 1 filter paper, and the methylene chloride extracts were combined and reduced to $5 \mathrm{ml}$ under reduced pressure at $60^{\circ} \mathrm{C}$. A $5-\mathrm{ml}$ volume of distilled water was added to the concentrated methylene chloride extract and acidified to $\mathrm{pH} 2.0$ with $6 \mathrm{~N} \mathrm{HCl}$. The two phases were mixed thoroughly and then separated by centrifugation at $10,000 \times g$ for $15 \mathrm{~min}$ at $4^{\circ} \mathrm{C}$, and the aqueous phase was discarded. The solvent was evaporated under reduced pressure at $60^{\circ} \mathrm{C}$, and the resulting crude mycolate was desiccated in vacuo for 48 h at $25^{\circ} \mathrm{C}$.

Samples were methylated using a modification of the procedure of Metcalfe and Schmitz (18). Approximately $100 \mathrm{mg}$ of dried residue was dissolved in $3 \mathrm{ml}$ of a $10 \%(\mathrm{wt} / \mathrm{vol})$ solution of boron trichloride in methanol (Sigma) and boiled for $7 \mathrm{~min}$ in a $100^{\circ} \mathrm{C}$ water bath. To the boiled mixture was added $5 \mathrm{ml}$ of methylene chloride and $5 \mathrm{ml}$ of distilled water, and it was shaken vigorously. The mixture was separated into two phases by centrifugation at $10,000 \times g$ for 15 min at $4^{\circ} \mathrm{C}$, and the aqueous-methanol phase was discarded. Solid materials formed at the interface were 
retained along with the methylene chloride phase, and the solvent was evaporated in a $60^{\circ} \mathrm{C}$ water bath. The resultant residue was desiccated in vacuo and stored at $-20^{\circ} \mathrm{C}$

The methylated residue, containing 10 to $20 \mathrm{mg}$ of material, was purified by preparative thin-layer chromatography on a glass plate $(10$ by $20 \mathrm{~cm}$ ) coated with Merck Silica Gel $\mathbf{P F}_{254}$ (Brinkmann Instruments, Westbury, N.Y.) and developed with petroleum ether (bp 40 to $50^{\circ} \mathrm{C}$ )-diethyl ether $(8: 2)$. The plates were air dried, and the lipid-containing bands were revealed by spraying with rhodamine $B$, prepared by the method of Laneelle (13): $0.1 \%$ (wt/vol) rhodamine B in ethanol diluted $1: 10$ with $0.25 \mathrm{M} \mathrm{KH}_{2} \mathrm{PO}_{4}$. Compounds migrating the same distance as a methylated corynomycolate standard were scraped from the plate, dried at $25^{\circ} \mathrm{C}$ for $18 \mathrm{~h}$, and eluted from the silica gel with distilled methylene chloride by filtering through glass wool. The rhodamine B remained absorbed to the silica gel.

Two to six micrograms of each dried eluate was redissolved in methylene chloride and injected into a Varian Aerograph 2800 Moduline dual-column gasliquid chromatograph (Varian, Norwalk, Conn.) equipped with a hydrogen flame detector, a programmer, a flow controller, and two stainless-steel columns ( $1 / 8$ inch by 6 feet; ca. 0.32 by $182.88 \mathrm{~cm}$ ) containing Chromosorb W (Johns-Manville, Englewood Cliffs, N.J.), 100/120 mesh (AW-DMCS), with $10 \%$ OV-1 as liquid phase. Conditions for analysis were: detector at $300^{\circ} \mathrm{C}$, injector at $300^{\circ} \mathrm{C}$, oven at $185^{\circ} \mathrm{C}$ programmed to $300^{\circ} \mathrm{C}$ at $6^{\circ} \mathrm{C} / \mathrm{min}$. The carrier gas was prepurified nitrogen flowing at $30 \mathrm{ml} / \mathrm{min}$. Pyrolysis fragments were identified by their retention times. Standards consisted of even, saturated, and unsaturated straightchain methyl esters of fatty acids from $C_{12}$ to $C_{26}$ and the corresponding fatty aldehydes of $\mathrm{C}_{14}, \mathrm{C}_{16}$, and $\mathrm{C}_{18}$ which were stabilized in $\mathrm{CS}_{2}$.

\section{RESULTS}

Cell wall fractions containing MA-AG-PG complexes obtained from strains 392-1 (biovar I) and 321D (biovar IV), together with strain 148A (biovar C-1), of $C$. genitalium were compared with a fraction extracted similarly from $C$. xerosis.

Neutral sugar composition. The neutral sugar composition of the MA-AG-PG complex of the three strains of $C$. genitalium was compared quantitatively with that of $C$. xerosis (Table 1). The molar ratio of the sugars was expressed with respect to arabinose, which was found in the greatest amount. The cell wall fractions of all the strains contained sugars characteristic of the corynebacteria of human origin, namely, the pentose arabinose and the hexose galactose, with a molar ratio of more than 2 to 1 in the fractions from $C$. genitalium and $C$. xerosis. The main difference between $C$. genitalium and C. xerosis was in the molar ratios of mannose and glucose. The molar ratios for mannose and glucose in the cell wall fraction of $C$. xerosis, were 0.06 and 0.26 , respectively, whereas
TABLE 1. Neutral sugar composition of the mycolic acid-arabinogalactan-peptidoglycan complex in the cell walls of Corynebacterium genitalium and Corynebacterium xerosis

\begin{tabular}{lcccc}
\hline & \multicolumn{4}{c}{ Molar ratio $^{a}$} \\
\cline { 2 - 5 } Neutral sugar & $\begin{array}{c}\text { C. xerosis } \\
\text { ATCC } \\
\end{array}$ & $\begin{array}{c}\text { C.geni- } \\
\text { talium } \\
\text { 392-1 } \\
\text { (biovar I) }\end{array}$ & $\begin{array}{c}\text { C.geni- } \\
\text { talium } \\
\text { 321D } \\
\text { (biovar } \\
\text { IV) }\end{array}$ & $\begin{array}{c}\text { C.geni- } \\
\text { talium } \\
\text { 148A } \\
\text { (biovar C- } \\
\text { 1) }\end{array}$ \\
\hline Arabinose & 1.00 & 1.00 & 1.00 & 1.00 \\
Galactose & 0.41 & 0.45 & 0.36 & 0.48 \\
Mannose & 0.06 & 0.32 & 0.24 & 0.45 \\
Glucose & 0.26 & 0.09 & 0.08 & 0.06 \\
Rhamnose & 0.13 & 0.13 & 0.03 & 0.06 \\
Ribose & 0.07 & 0.02 & 0.08 & 0.09 \\
\hline
\end{tabular}

${ }^{a}$ Molar ratios are expressed with respect to arabinose.

the average molar ratios in $C$. genitalium were 0.33 and 0.08 , respectively. The remaining detectable sugars of the MA-AG-PG complexes were rhamnose and ribose. Rhamnose occurred at a slightly higher molar ratio in C. xerosis and C. genitalium 392-1 (biovar I) than in C. genitalium 321D (biovar IV) and 148A (biovar C-1), but the difference was not significant. The ratios of ribose in the cell wall fractions of both $C$. xerosis and $C$. genitalium were uniformly very low, with ratios of 0.02 to 0.09 .

Amino acid and amino sugar composition. The quantitative amino acid and amino sugar composition of the MA-AG-PG complexes in the cell walls of $C$. genitalium and $C$. xerosis are given in Table 2. The values are expressed as molar ratios to glutamic acid even though alanine was present in greater concentrations. In all the cell wall fractions the major amino acids were glutamic acid, alanine, and diaminopimelic acid which occurred in similar molar ratios. The relative proportions of the remaining minor amino acids of the MA-AG-PG complex also were similar in these four strains of corynebacteria. They were aspartic acid, threonine, serine, proline, valine, isoleucine, leucine, tyrosine, phenylalanine, lysine, histidine, and arginine. No component corresponding to the methionine standard was detected in any fraction. The amino sugars muramic acid and glucosamine were present in the four cell wall fractions, but the molar ratios of the two amino sugars were slightly higher in $C$. xerosis. A significant variation in the MA-AG-PG complexes was noted only with respect to galactosamine. $C$. xerosis contained galactosamine in a molar ratio of 0.62 in contrast to C. genitalium 392-1 (biovar I), which contained a smaller molar ratio of 0.27 , whereas no galactosamine was detected in either C. genitalium 321D (biovar IV) or C. genitalium 
148A (biovar C-1).

Mycolic acids. On analysis of $C$. xerosis and the three strains of $C$. genitalium, corynomycolates were detected in all the strains. A characteristic band which is typical of corynomycolates was observed on thin-layer chromatography plates of all four strains. Each of the bands was eluted and examined by gas-liquid chromatography. The fatty acid ester and aldehyde pyrolysis fragments of the corynomycolates were different in C. xerosis and the strains of $C$. genitalium. C. xerosis corynomycolates gave rise to saturated fatty acid and aldehyde fragments, whereas the strains of $C$. genitalium 392-1 (biovar I) and 321D (biovar IV) yielded monounsaturated fragments. In addition, traces of asyet-unidentified pyrolysis fragments were found in the three strains of $C$. genitalium.

\section{DISCUSSION}

The coryneform group of bacteria together with genera of the Actinomycetales including Actinomyces, Bacterionema, Bifidobacterium, Mycobacterium, Nocardia, and Rothia present a number of unresolved problems in taxonomy and classification. Members of the various genera cannot be differentiated from the corynebacteria on the basis of cellular morphology alone since, at some stage in their growth cycle on artificial media, they all produce "straight to slightly curved rods with irregularly staining segments and sometimes granules" (19). Certain other morphological and physiological characteristics do contribute towards separating the corynebacteria from the other similar organisms, such as acid fastness, the presence of branching forms and filamentous or myelium-like growth, and the requirement for anaerobic conditions for growth. However, the mycobacteria and nocardia are strict aerobes which is characteristic of the pathogenic $C$. genitalium when grown on Tween 80 agar, and even though strains of $C$. genitalium are not acid fast this property is not a conclusive criterion for their identification since some strains of mycobacteria and all of the nocardia are at best weakly acid fast.

In the most recent edition of Bergey's Manual (19), distinctive cell wall components are considered essential taxonomic criteria for a species to be a member of the genus Corynebacterium and specifically of the human corynebacteria. Previous studies of the cell walls of the parasitic and pathogenic corynebacteria of human origin have detected the presence of an arabinogalactan polymer and the amino acids alanine, glutamic acid, and diaminopimelic acid $(1,19)$. Organisms having these major cell wall components include the bacterionema, corynebacteria, mycobacteria, and nocardiae (19).
TABLE 2. Amino acid and amino sugar composition of the mycolic acid-arabinogalactanpeptidoglycan complex in the cell walls of Corynebacterium genitalium and Corynebacterium xerosis

\begin{tabular}{|c|c|c|c|c|}
\hline \multirow[b]{2}{*}{$\begin{array}{l}\text { Amino acids } \\
\text { and amino } \\
\text { sugars }\end{array}$} & \multicolumn{4}{|c|}{ Molar ratios $^{a}$} \\
\hline & $\begin{array}{c}\text { C. xerosis } \\
\text { ATCC } \\
373\end{array}$ & $\begin{array}{c}\text { C. geni- } \\
\text { talium } \\
392-1 \\
\text { (biovar I) }\end{array}$ & $\begin{array}{c}\text { C. geni- } \\
\text { talium } \\
\text { 321D } \\
\text { (biovar } \\
\text { IV) }\end{array}$ & $\begin{array}{c}\text { C. geni- } \\
\text { talium } \\
148 \mathrm{~A} \\
\text { (biovar } \\
\text { C-1) }\end{array}$ \\
\hline $\begin{array}{l}\text { Glutamic } \\
\text { acid }\end{array}$ & 1.00 & 1.00 & 1.00 & 1.00 \\
\hline Alanine & 1.21 & 1.29 & 1.24 & 1.29 \\
\hline $\begin{array}{l}\text { Diaminopi- } \\
\text { melic acid }\end{array}$ & 0.92 & 0.96 & 0.78 & 0.76 \\
\hline $\begin{array}{l}\text { Muramic } \\
\text { acid }^{b}\end{array}$ & 1.27 & 0.92 & 0.94 & 1.00 \\
\hline $\begin{array}{l}\text { Glucosa- } \\
\text { mine }^{b}\end{array}$ & 0.86 & 0.60 & 0.77 & 0.71 \\
\hline $\begin{array}{l}\text { Galactosa- } \\
\text { mine }^{b}\end{array}$ & 0.62 & 0.27 & $\mathbf{N D}^{c}$ & $\mathrm{ND}$ \\
\hline Aspartic acid & 0.10 & 0.10 & 0.13 & 0.15 \\
\hline Threonine & 0.06 & 0.07 & 0.08 & 0.09 \\
\hline Serine & 0.07 & 0.07 & 0.09 & 0.08 \\
\hline Proline & 0.06 & 0.06 & 0.09 & 0.09 \\
\hline Glycine & 0.08 & 0.12 & 0.15 & 0.14 \\
\hline Valine & 0.05 & 0.05 & 0.08 & 0.09 \\
\hline Methionine & $\mathrm{ND}$ & $\mathrm{ND}$ & ND & ND \\
\hline Isoleucine & 0.07 & 0.03 & 0.06 & 0.06 \\
\hline Leucine & 0.09 & 0.10 & 0.10 & 0.11 \\
\hline Tyrosine & 0.02 & 0.02 & 0.03 & 0.03 \\
\hline $\begin{array}{l}\text { Phenylala- } \\
\text { nine }\end{array}$ & 0.03 & 0.03 & 0.07 & 0.03 \\
\hline Lysine & 0.08 & 0.08 & 0.07 & 0.05 \\
\hline Histidine & 0.02 & 0.02 & 0.02 & 0.03 \\
\hline Arginine & 0.06 & 0.06 & 0.04 & 0.05 \\
\hline
\end{tabular}

${ }^{a}$ Amino acid and amino sugar composition was based on a calibration mixture, containing $10 \mathrm{nmol}$ of each component. Molar ratios were then calculated with respect to glutamic acid.

${ }^{b} \mathrm{Hydrolysis}$ performed in $4 \mathrm{~N} \mathrm{HCl}$ at $100^{\circ} \mathrm{C}$ for $8 \mathrm{~h}$.

${ }^{c}$ ND, Not detected.

On the basis of cell wall analysis, the three strains of $C$. genitalium examined could be assigned to one of these three genera. However, the results of the neutral sugar analysis of the cell wall of the three strains of $C$. genitalium showed the presence of the characteristic arabinogalactan in which the pentose "arabinose" and the hexose "galactose" were detected in equimolar ratios when compared to the reference strain $C$. xerosis, a recognized member of the genus Corynebacterium (19). This confirmed that they are Corynebacterium species. This analysis also showed that $C$. genitalium contained a larger amount of an additional component mannose, whereas a larger proportion of glucose was found in C. xerosis. Differences in these two sugars can be indicative of different species (19). 
The amino acid and amino sugar compositions of the cell wall preparations of the three strains of $C$. genitalium also supported the evidence derived from the sugar analysis, namely, that the strains belonged to one of the genera of the Corynebacterium - Mycobacterium - Nocardia group. Of the major components the molar ratios of glutamic acid, alanine, diaminopimelic acid, muramic acid, and glucosamine were similar in all strains of $C$. genitalium and also in C.xerosis. The lack of galactosamine in $C$. genitalium biovar IV and biovar C-1 suggests that $C$. genitalium might be composed of more than one species.

The sensitivities of the amino acid and amino sugar analyses were at extended levels, enabling the quantitation of minor amino acids in 0.2nmol quantities per sample. Whether the minor amino acid components are part of the cell wall complex proper, or cytoplasmic remnants, or whether they represent the remains of surface protein layers as exemplified by the $M$ antigens of streptococci, remains to be determined.

The mycolic acid found in corynebacteria is designated corynomycolic acid and contains 32 to 36 carbon atoms, in contrast to those of nocardiae and mycobacteria which contain, respectively, 48 to 58 and 78 to 85 carbon atoms (19). The three strains of $C$. genitalium and the control C. xerosis contained mycolates of 32 to 36 carbon atoms which confirmed that they belonged to the genus Corynebacterium. Therefore, the previous assignment of $C$. genitalium to the genus Corynebacterium on the basis of biological characteristics has been confirmed by the cell wall analysis of their neutral sugars, amino acids, amino sugars, and mycolates. Moreover, some differences in the cell wall constituents suggest that these corynebacteria may consist of more than one species.

\section{ACKNOWLEDGMENT}

This research was supported in part by the Foundation of the College of Medicine and Dentistry of New Jersey.

\section{REPRINT REQUESTS}

Address reprint requests to: Dr. Geoffrey Furness, Department of Microbiology, New Jersey Medical School, 100 Bergen Street, Newark, NJ 07103.

\section{LITERATURE CITED}

1. Barksdale, L. 1970. Corynebacterium diphtheriae and its relatives. Bacteriol. Rev. 34:378-422.

2. Fernell, W. R., and H. K. King. 1953. Simultaneous determination of pentose and hexose in mixtures of sugars. Analyst 78:80-83.

3. Furness, G., and G. W. Csonka. 1966. Isolation of diphtheroids from non-gonococcal urethritis. Br. J. Vener. Dis. 42:185-190.

4. Furness, G., and A. T. Evangelista. 1976. Infection of nonspecific urethritis patient and his consort with a pathogenic species of non-specific urethritis corynebacteria, Corynebacterium genitalium. n. sp. Invest. Urol. 14:202-205.

5. Furness, G., A. T. Evangelista, and Z. Kaminski. 1977. Corynebacterium genitalium (NSU corynebacteria): biological reactions differentiating commensals of the urogenital tract from the pathogens responsible for urethritis. Invest. Urol. 15:23-27.

6. Furness, G., M. H. Kamat, Z. Kaminski, and J. J. Seebode. 1971. The etiology of idiopathic epididymitis. J. Urol. 106:387-392.

7. Furness, G., M. H. Kamat, Z. Kaminski, and J. J. Seebode. 1971. Isolation of corynebacteria from nonspecific urethritis. J. Urol. 106:557-561.

8. Furness, G., M. H. Kamat, Z. Kaminski, and J. J. Seebode. 1973. An investigation of the relationship of nonspecific urethritis corynebacteria to the other microorganisms found in the urogenital tract by means of a modified chocolate agar medium. Invest. Urol. 10:387-391.

9. Furness, G., M. H. Kamat, Z. Kaminski, and J. J. Seebode. 1974. The relationship of epididymitis to gonorrhea. Invest. Urol. 11:312-314.

10. Kanetsuna, F. 1968. Chemical analyses of mycobacterial cell walls. Biochim. Biophys. Acta 158:130-143.

11. Kesler, R. B. 1967. Rapid quantitative anion-exchange chromatography of carbohydrates. Anal. Chem. 39:1416-1419.

12. LaCave, C., J. Asselineau, and R. Toubiana. 1967. Sur quelques constituants lipidiques de Corynebacterium ovis. Eur. J. Biochem. 2:37-43.

13. Laneelle, G. 1963. Nature des acides mycoliques de $M y$ cobacterium paratuberculosis: application de la chromatographic sur couche mince a leur fractionnement. C. R. Acad. Sci. 257:781-783.

14. Lechevalier, M. P., A. C. Horan, and H. Lechevalier. 1971. Lipid composition in the classification of nocardiae and mycobacteria. J. Bacteriol. 106:313-328.

15. Lechevalier, M. P., H. Lechevalier, and A. C. Horan. 1973. Chemical characteristics and classification of nocardiae. Can. J. Microbiol. 19:965-972.

16. Lee, Y. C., J. F. McKelvy, and D. Lang. 1969. Rapid automatic analysis of sugar components of glycoproteins. II. Neutral sugars. Anal. Biochem. 27:569-574.

17. Lowry, O. H., N. J. Rosebrough, A. L. Farr, and R. J. Randall. 1951. Protein measurement with the Folin phenol reagent. J. Biol. Chem. 193:265-275.

18. Metcalfe, L. D., and A. A. Schmitz. 1961. The rapid preparation of fatty acid esters for gas chromatographic analysis. Anal. Chem. 33:363-364.

19. Rogosa, M., C. S. Cummins, R. A. Lelliottt, and R. M. Keddie. 1974. Coryneform group of bacteria, $p$ 599-632. In R. E. Buchanan and N. E. Gibbons (ed.), Bergey's manual of determinative bacteriology, 8th ed. The Williams and Wilkins Co., Baltimore.

20. Schleiffer, K. H., and O. Kandler. 1972. Peptidoglycan types of bacterial cell walls and their taxonomic implications. Bacteriol. Rev. 36:407-477.

21. Scott, T. A., and E. H. Melvin. 1953. Determination of dextran with anthrone. Anal. Chem. 25:1656-1661.

22. Senn, M., T. Ioneda, J. Pudles, and E. Lederer. 1967. Spectrometrie de masse de glycolipides. I. Structure du "cordfactor" de Corynebacterium diphtheriae. Eur. J. Biochem. 1:353-356.

23. Spackman, D. H., W. H. Stein, and S. Moore. 1958. Automatic recording apparatus for use in the chromatography of amino acids. Anal. Chem. 30:1190-1206.

24. Welby-Guisse, M., M. A. Laneelle, and J. Asselineau. 1970. Structure des acides corynomycoliques de $C$. hofmanii, et leur implication biogenetique. Eur. J. Biochem. 13:164-167. 